\title{
The fine structure of the cell wall of hardwoods on transverse-fracture surfaces
}

\section{J. Sell, T. Zimmermann}

EMPA, Überland str. 128, CH-8600 Dübendorf

Subject Transverse-fracture surfaces of tension-loaded fiber cells of hardwood samples (beech, Fagus sylvatica; oak, Quercus robur, Q. petraea) studied by means of a high-resolution FE SEM showed predominantly marked radial orientation of the cellulosic fibrils of the secondary wall layer 2 (S2). In other words, the S2 fibrils are perpendicularly oriented to the adjacent S1 and S3 layers. This fibril arrangement of hardwood fiber cells corresponds with former findings on the fine structure of fracture surfaces of softwood tracheids. All cell wall layers of hardwood vessels, however, exhibit a polylaminated concentric structure.

'ntroduction In the course of recent studies on tension-fracture surfaces of several softwoods by means of a high-resolution field emission SEM (FE SEM), new findings on the structure of the cell wall layer S2 were obtained [Sell, Zimmermann $1993 \mathrm{a}$ and b]. This is probably of major importance for the mechanical properties of the cell wall and, therefore, of the entire wood substance, since the $S 2$ is the by far thickest cell wall layer. It had been observed that on transverse sections the cellulosic fibrils in the S2 are apparently not (or at least not only) arranged in concentric (circumferential) sublayers, as assumed by the majority of authors until now, but oriented in more or less radial assemblies, relative to the cell axis. This means, in other words, that the orientation of the fibrils (and implicitly of the lignin matrix, too) is more or less perpendicular to the thin adjacent layers S1 and S3. The origin of these radial S2 structures is explained by a higher packing density and stronger adhesion of the fibrils in the radial direction compared with the circumferential direction. This results in a sandwich-like overall structure of the wooden cell wall (i.e. the double wall of adjacent cells, respectively) which is believed to be beneficial for the stiffness of the compound structure of wood [Booker, Sell 1998; Sell 1994].

The goal of the present work is to study the fine structure of the cell wall, particularly of the fiber cells, of selected hardwoods ipecies using the same techniques as previously with softwoods.

Materials and methods As with former studies, bending tests were used to loosen the cell wall structure and thus enable a

microscopic differentiation of its elements on transverse-fracture surfaces in the area of outer tension zones.

Small rods of clear wood (cross section $20 \mathrm{~mm} \times 20 \mathrm{~mm}$ ) of two hardwoods (beech, Fagus sylvatica; oak, Quercus robur, $Q$. petraea) were each loaded until fracture at two different temperatures $\left(20^{\circ}\right.$ and $\left.60^{\circ} \mathrm{C}\right)$, three different wood moisture contents (equilibrium $\mu \mathrm{C}$ at $20^{\circ} \mathrm{C}$ and $35,65,85$ percent relative humidity) and three load durations (impact bending, short-term and long-term static bending). For the SEM studies, samples of the outermost tension zones of the fracture surfaces were prepared and sputtered with platinum. The microscopic study was carried out by means of a high resolution FE SEM (JEOL $6300 \mathrm{~F}$ ).

Results As is the case on softwood tracheids, S2 fibril agglomerations on the hardwoods investigated can be differentiated on the transverse-fracture surface of the fiber cell walls. These run mainly transverse or partly transverse to the middle layers and also to the S1 and S3 layers, and are therefore radially oriented with relation to the cell axis (Figure 1). In a few individual cases there are also concentric S2 fracture structures as well as radial structures in one and the same cell wall (Figure 2).

When viewed with a higher resolution, also shown by investigations on softwoods [Sell, Zimmermann 1993 a and b], indi- vidual cellulosic fibrils or microfibril bundles with a diameter of 10 to $100 \mathrm{~nm}$ are visible (Figure 3). Especially with long-term bending samples, the fibrils are often agglomerated to large radial structures which extend over the complete S2 layer (Figure 4).

This radial fibril orientation of the cell wall appeared only with fiber cells (libriform and tracheid fibers), but not with paren-

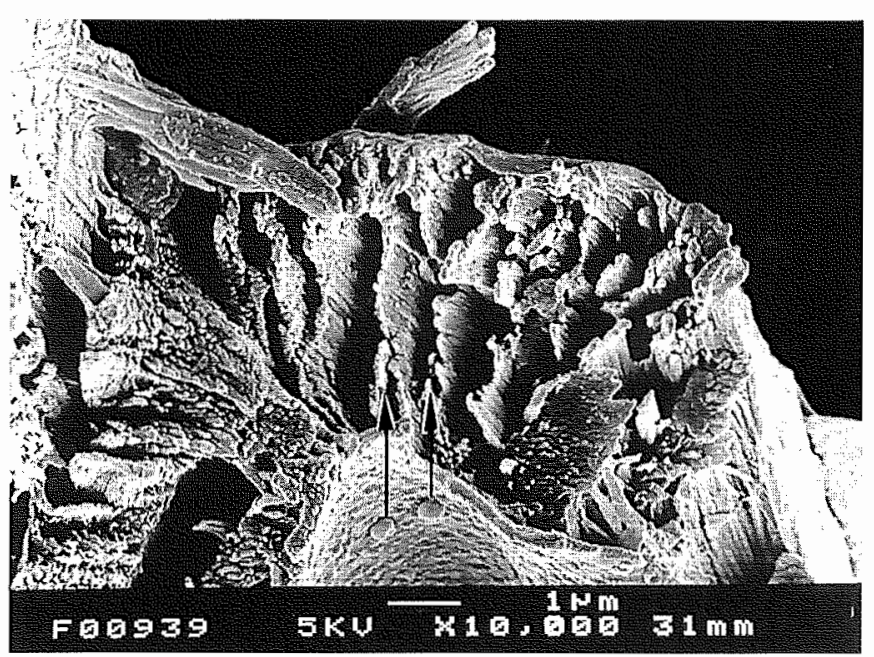

Fig. 1. Transverse-fracture surface (tension zone) of a libriform fiber of beech; shorttime static bending test at $20^{\circ} \mathrm{C} / 85$ percent $\mathrm{RH}$. Relatively intense deformed cell wall, the radial agglomerations (arrows) extend over the whole cross section of the $S_{2}$ Bild 1. Querbruchfläche (Zugzone) einer Libriformfaser von Buche; statische Kurzzeitbiegung bei $20{ }^{\circ} \mathrm{C} / 85 \%$ r. F. Relativ stark verformte Zellwand; die radialen Agglomerationen (Pfeile) reichen über den gesamten S2-Querschnitt

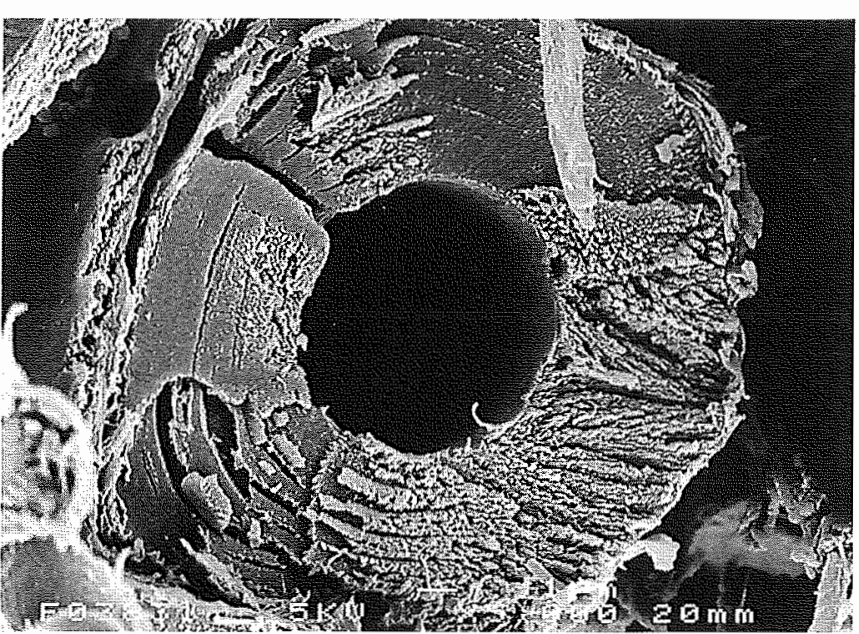

Fig. 2. Transverse-fracture surface (tension zone) of a libriform fiber of beech; impact bending at $20{ }^{\circ} \mathrm{C} / 35$ percent $\mathrm{RH}$. Brittle fracture with an only partially loosened fibril/matrix structure. The fibrils are oriented partly lamellar and partly radial Bild 2. Querbruchfläche (Zugzone) einer Libriformfaser von Buche; Schlagbiegung bei $20{ }^{\circ} \mathrm{C} / 35 \%$ r.F. Sprödbruch mit nut teilweise aufgelockertem Fibrillengefüge. Die Fibrillen sind teils eher lamellar, teils eher radial orientiert 


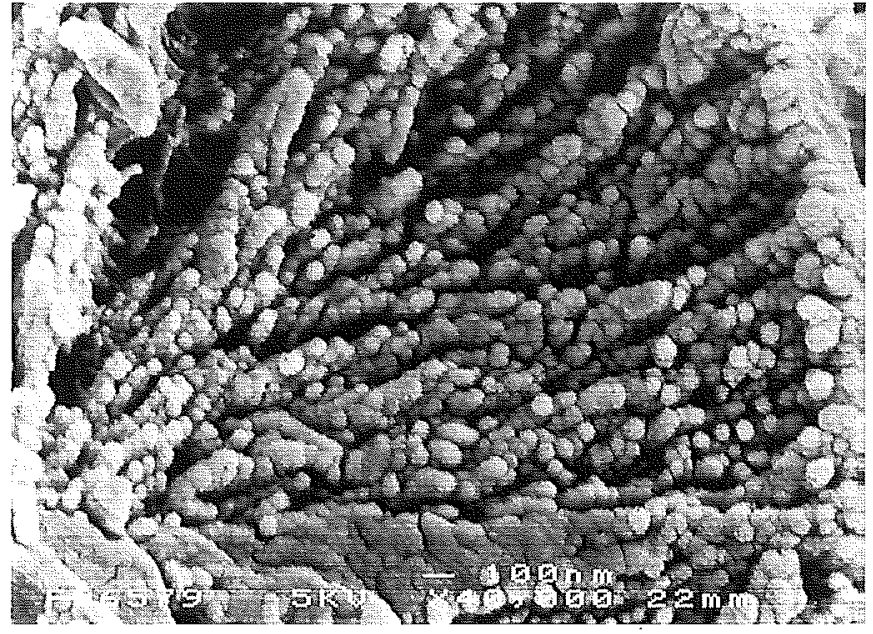

Fig. 3. Transverse-fracture surface (tension zone) of an $S_{2}$ area of a fiber cell wall of oak; impact bending at $60{ }^{\circ} \mathrm{C} / 35 \% \mathrm{RH}$. With high resolutions some cellulose fibrils with radial orientations and diameters of 10 to $100 \mathrm{~nm}$ become visible

Bild 3. Querbruchfläche (Zugzone) eines Zellwandbereiches einer Faserzelle von Eiche; Schlagbiegung bei $60{ }^{\circ} \mathrm{C} / 35 \%$ r. F. Bei hoher Auflösung werden einzelne in radialer Vorzugsorientierung angeordnete Cellulosefibrillen der S2 - mit Durchmessern von 10 bis $100 \mathrm{~nm}$ erkennbar

chyma and vessel cells. The latter exhibited a polylaminated concentric structure of the transverse-fracture surface.

As already observed on softwoods, the impact of temperature, moisture, and load duration on the structure of the tension fracture surface [Zimmermann et al. 1994] also occurred on the hardwoods: higher temperature, increasing moisture, increasing load duration produce a clear indication of ductile fractures with strongly fissured cell wall structures.

Conclusions The more or less clear radial orientation of the fibril agglomerations - and thus implicitly also the lignin matrix of the cell wall - has been confirmed by several independent investigations employing very different methods. For instance transmission electron microscopic investigations [Singh et al. 1998; Pöhler 1995] and decomposition studies of the cell wall with fungi [Schwarze, Engels 1998] also provide additional confirmation of radial arrangement of lignin and/or cellulose of the S2 layer.

Our hypothesis, already advanced in 1993, has been strengthened: together with $S 1$ and $S 3$, radial cellulose (and lignin) structures of the S2 form a sandwich-type cross section of the cell wall. This benefits its flexibility and bending strength and therefore promotes the required high axial compression strength of the wood in a standing tree.

However, it has still not been conclusively explained why different microscopical, chemical, and other studies used in numerous former investigations have exhibited both concentric and/or radial arrangements of the cellulose fibril/lignin matrix structure of the S2 of the cell wall. In our opinion it is quite plausible that these structures do in fact coexist.

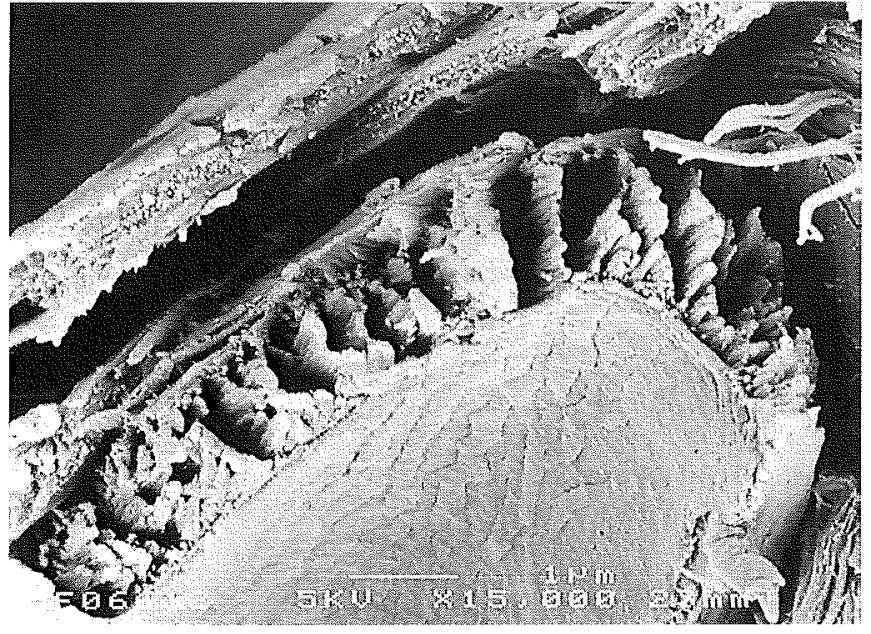

Fig. 4. Transverse-fracture surface (tension zone) of an area of a fiber cell wall of oak; long-term bending at $20{ }^{\circ} \mathrm{C} / 35 \% \mathrm{RH}$. The cellulose fibrils are agglomerated to larger radial structures which often extend over the whole cross section of the $S_{2}$

Bild 4. Querbruchfläche (Zugzone) eines Zellwandbereiches einer Faserzelle von Eiche; Langzeitbiegung bei $20{ }^{\circ} \mathrm{C} / 35 \% \mathrm{r}$. F. Die Cellulosefibrillen sind zu grösseren radialen Strukturen agglomeriert, die oftmals über den gesamten S2-Durchmesser reichen

\section{References}

Booker R, Sell J (1998) The nanostructure of the cell wall of softwoods and its functions in a living tree. Holz Roh-Werkstoff 56: $1-8$

Pöhler E (1995) Chemische und mikroskopische Untersuchungen zum Delignifizierungsverlauf beim ASAM- und Kraftaufschluss.

Diplomarbeit, Universität Hamburg

Schwarze FWMR, Engels J (1998) Cavity formation and the exposure of peculiar structures in the secondary wall (S2) of tracheids and fibres by wood degrading basidiomycetes.

Holzforschung 52: 117-123

Sell J, Zimmermann T (1993a) Das Gefüge der Zellwandschicht S2 - Untersuchungen mit dem Feldemissions-Rasterelektronenmikroskop an Querbruchflächen von Fichten- und Tannenholz. Forschungs- und Arbeitsberichte EMPA Abteilung Holz, 115/28: 1 26

Sell J, Zimmermann T (1993b) Radial fibril agglomerations of the $\mathrm{S} 2$ on transverse fracture surfaces of tracheids of tension-loaded spruce and white fir. Holz als Roh- und Werkstoff 51: 384

Sell J (1994a) Confirmation of a sandwich-like model of the cell wall of softwoods by the light microscope. Holz Roh-Werkstoff 52: 234

Sell J (1994b) Mechanical aspects of new SEM observations on the fibril/matrix structure of the $\mathrm{S}_{2}$ layer of softwood tracheids. Proc. Internat. Congr. Plant Biomechanics, Montpellier. Edition Scientifiques Elsevier, Paris: 163-164

Singh AP, Sell J, Schmitt U, Zimmermann T, Dawson B (1998)

The S2 layer in Pinus radiata mild compression wood tracheids is radially striated. Holzforschung In press

Zimmermann T, Sell J, Eckstein D (1994) Rasterelektronenmikroskopische Untersuchungen an Zugbruchflächen von Fichtenholz. Holz Roh-Werkstoff 52: 223-229 